\title{
PERANAN SUPERVISI PENDIDIKAN SEBAGAI FASILISATOR UPAYA PENGEMBANGAN PROFESIONALITAS PENDIDIK DALAM MENINGKATKAN KEDISIPLINAN PESERTA DIDIK TUJUAN MENCAPAI MUTU PENDIDIKAN NASIONAL
}

\author{
Miftahul Jannah \\ Miftahuljannah281198@gmail.com
}

\begin{abstract}
ABSTRAK
Pentingnya pendidikan bagi setiap individu yaitu dalam membentuk dan mengembangkan kepribadian yang baik. Pendidikan tidak hanya berupa materi pembelajaran di kelas tetapi juga bagaimana mengembangkan potensi dan kreativitas individu serta peduli terhadap lingkungan sekitar. Kedisiplinan merupakan salah satu contoh karakter yang harus ada dalam diri individu terdidik yang mana tak terlepas dari peran seorang pendidik. Guru merupakan pendidik dalam sebuah pendidikan (sekolah) yang siap melaksanakan fungsinya sebagaimana mesti nya. Supervisi merupakan suatu usaha dalam memberi pelayanan agar seorang guru menjadi lebih professional dalam mengemban amanah yang dipegangnya untuk menjadi seorang pendidik yang baik. Dalam hal ini, tidak terlepas dari peran seorang supervisor yang memberikan arahan dan panduan dalam pembelajaran. Supervisi disini berkaitan dengan kemampuan kepala sekolah dalam memberikan arahan, bimbingan serta memberikan bantuan kepada serorang pendidik atau guru.
\end{abstract}

Kata Kunci: Pendidikan, pendidik, peserta didik, disiplin, supervisi

\section{BAB I}

\section{PENDAHULUAN}

Pendidikan adalah suatu hal yang penting bagi setiap individu dalam membentuk dan mengembangkan kepribadian yang baik, sehingga pendidikan sangat berbeperan penting dalam suatu kehidupan manusia. Pendidikan tidak hanya berupa materi pembelajaran di kelas tetapi juga bagaimana mengembangkan potensi dan kreativitas individu serta peduli terhadap lingkungan sekitar.

Namun faktanya sekarang pendidikan seolah hanya memberikan materri pembelajaran yang harus dicapai dikelas sehingga potensi dan keterampilan peserta didik terabaikan, yang berakibat terbentuknya sikap individualitas dan sikap santun terhadap guru mulai hilang. Sebagaimana yang terjadi baru-baru ini, seorang peserta didik memperolok-olokkan gurunya, ini merupakan suatu fakta yang berda dilluar nalar, namun inilah yang terjadi saat ini. 
Ada apa dengan pendidikan di Indonesia saat ini, sehingga terus mengalami penurunan, yang tentu saja sangat memprihatinkan dimana pendidikan merupakan sarana untuk kemajuan Negara. Di era globalisasi ini meningkatkan pendidikan haruslah segra dilaksanakan agar mampu bersaing dengan Negara lain. Dengan memperbaiki pendidikan, maka sumber daya manusia tentu juga akan lebih baik yang juga berdampak pada lapangan pekerjaan. Setelah diamati, masalah serius terdapat pada peningkatan mutu pendidikan baik itu pendidikan formal maupun non formal.

Berdasarkan paparan yang telah dijelaskan penulis mencoba merumuskan permasalan diantaranya(1)Apa itu Disiplin? (2)Bagaimana seorang pendidik itu?(3)Bagaimana peranan supervisi Pendidikan dalam meningkatkan mutu pendidikan? Tujuan penulis dari penulisan ini adalah (1)Menjelaskan pentingnya kedisiplinan bagi peserta didik,(2)Menjelaskan karakteristik seorang pendidik (3)Menjelaskan peranan surpervisi pendidikan dalam menigkatan mutu pendidikan

\section{BAB II}

\section{PEMBAHASAN}

Disiplin adalah sebuah tindakan atau perilaku (sikap) tidak adanya paksaan yang menunjukkan keteraturan internal terhadap peraturan atau norma-norma yang berlaku. Hal ini dapat terlihat dalam keseharianny yang dapat membedakan atau memahami mana perilaku yang baik dan mana yang salah serta dapat mentaati peraturan tanpa adanya reward dan punishment yang telah dijelaskan oleh Aulina (Aulina, 2013)

Dengan disiplinnya seorang siswa dapat memberikan dampak yang baik seperti tumbuh pada nya kepercayaan dan control terhadap dirinya sendiri serta kepedulian pada akan membuatnya memiliki kecakapan dalam belajar dan meraih prestasi yang bagus dalam pendidikan yang ditempuhnya, yang juga akan berpengaruh terbentuknya akhlak yang baik. Dalam mendidik anak disiplin perlu diterapkan, tegas dalam hal apa yang harus dilakukan, dan apa yang dilarang dan tidak boleh dilakukan. Fungsi utama disiplin adalah untuk mengajar mengendalikan diri dengan mudah, menghormati dan mematuhi otoritas yang dijelaskan oleh Gunarsa dalam Maralih (Maralih, 2014)

Dalam Undang -Undang Sistem Pendidikan Nasional Tahun 2003 disebutkan bahwa guru harus memiliki 4 kompetensi yaitu, kepribadian, pedagogik, professional dan sosial. Akan tetapi tidak semua guru memiliki keempat kompetensi tersebut, hal ini terlihat dilapangan dalam menjalankan tugasnya sebagai seorang guru yang kurang baik, sehingga muncul antatra perbedaan hasil dengan kualitas pendidikan yang dihasilkan oleh masingmasiing guru. Seorang guru harus mampu menciptakan situasi dan kondisi pembelajaran yang kondusif, menguasai kelas, menguasai materi pebelajaran serta terampil menerapkan berbagai metode dalam proses belajar serta mendidik siswa di sekolah.

Selain itu permasalahan yang terjadi adalah rendahnya kualitas kepala sekolah dalam pelaksanaa supervise terhadap guru. Dengan faktor penyebab nya dalah kesukaran 
kepala sekolah dalam pelaksanaanya seperti terbatasnya kemampuan propesionalitas, terbatasnya waktu, terbatasnya petunjuk pelaksanaan dan terbatasnya biaya yang di jelaskan oleh Imran dalam Maralih (Maralih, 2014)

Dalam mewujudkan karakter disiplin seorang siswa akan terlihat dalam proses pembelajaran yang diikuti oleh siswa dengan hikmat, nyaman, tenang serta ditegakkannya nilai dan norma yang berlaku dan sesuai. Hal ini berkaitan dengan tujuan dari pendidikan nasional adalahpengendalian diri siswa harus diperhatikan oleh pendidik atau seorang guru di samping tugasnya dalam pengembangan intelektual siswa atau peserta didik yang telah di jelaskan oleh Fiana (Fiana, Fani julia, 2013)

Supervise adalah suatu proses untuk menerapkan pekerjaan yang telah dilaksanakan, memberikan penilaian serta diperlukan sedikitnya koreksi terhadap pekerjaan yang dilakukan sesuai dengan yang telah direncanakan. Supervise merupakan suatu usaha dalam memberi pelayanan agar seorang guru menjadi lebih professional dalam mengemban amanah yang dipegangnya untuk menjadi seorang pendidik yang baik oleh Manulang dalam Maralih (Maralih, 2014)

Supervisi merupakan suatu bentuk perngawasan terhadap kegiatan pendidikan dalam dunia pendidikan, bukan hannya sekedar pengawasan terhadap fisik material, tetapi prose belajar mengajar serta terhadap situasi. Supervisi pendidikan meerupakan suatu bentuk koordinir atau pengawasan dan bimbingan secara berkelanjutan untuk pertumbuhan guru-guru disekolah baik secara individual maupun secara kolektif, dengan tujuan agar tewujudkan seluruh fungsi pengajaran yang telah direncanakan dapat dicapai, sehingga dalam memberikan stimulir atau pengajaran dan bimbingan terhadap siswa lebih optimal serta mereka mampu dan lebih cakap berpatisipasi dalam masyarakat demokrasi modern oleh Bordman dalam Maralih (Maralih, 2014)

Pada dasarnya supervise berkaitan dengan kemampuan kepala sekolah dalam memberikan arahan, bimbingan serta memberikan bantuan kepada serorang pendidik atau guru. Namun kenyataan dilapangan, pelaksanaan nya masih kurang, yang terlihat dalam keseharian seorang pendidik yang masih enggan dan tidak meningkatb kualitas kerjanya, yang sangat mengganggu proses pembelajaran disekolah. Guru yang telah disupervisi dapat merencanakan dan menjalankan proses pembelajaran yang baik bila dibandingkan dengan yang belum disupervisi hanya menjalankan tugas dan tanggung jawabnya sebagai tenaga pendidik. Hal ini berbeda dengan guru-guru yang telah disupervisi, guru lebih giat dan berusaha untuk memberikan kualitas proses pembelajaran yang baik dalam menghasilkan mutu yang berkualitas.

Hal ini tidak terlepas dari peran guru inisiatif dan kreatif dalam upaya analisis pembelajaran dan permasaalhan yang ditemukan dalam rangka meningkatkan kualitas yang baik berkelanjutan. Dalam hal ini peran supervisor sebagai fasilitator, dengan contoh dalam menumbuhkan motivasi guru yang tinggi dalam pengembangan keprofesionalan guru seperti yang dikemukakan oleh Sabandi (Sabandi, 2013) 


\section{BAB III}

\section{PENUTUP}

Kualitas atau mutu pendidikan di Indonesia masih tergolong rendah dibandingkan dengan negara-negara lain, bahkan bisa dikatakan tertinggal. Hal ini disebabkan oleh kurang efektifitas, efisiensi dan standarisasi serta supervisor yang belum optimal menjalankan. Sehingga berdampak pada hasil yang tidak sesuai dengan tujuan yang telah direncanakan. Salah satu solusi dalam permasalahan ini adalah supervisi pendidikan yang dilaksanakan lebih optimal dan efektif.

\section{DAFTAR PUSTAKA}

Aulina, C. N. (2013). Penanaman Disiplin Pada Anak Usia Dini. Pedagogia, 2(1), 36-49. Retrieved fromhttp://ojs.umsida.ac.id/index.php/pedagogia/article/view/45/51

Fiana, Fani julia, dkk. (2013). Disiplin Siswa di Sekolah dan Implikasinya dalam Pelayanan Bimbingan dan Konseling. Konselor, Jurnal Ilmiah Konseling, 2(23), 26-33. Retrieved from http://ejournal.unp.ac.id/index.php/konselor/article/view/1733

Maralih. (2014). Peranan Supervisi Dalam Peningkatan Kualitas Pendidikan. QATHRUNA, 1(1), 179-192. Retrieved from http://jurnal.uinbanten.ac.id/index.php/qathruna/article/view/251

Sabandi, A. (2013). Supervisi Pendididikan Untuk Pengembangan Profesionalitas Guru Berkelanjutan. Pedagogi, Jurnal Ilmiah Ilmu Pendidikan, XIII(2), 1-9. Retrieved from http://ejournal.unp.ac.id/index.php/pedagogi/article/view/4275 